\title{
Video Pembelajaran Berbantuan Youtube untuk Meningkatkan Daya Tarik Siswa Belajar Perubahan Wujud Benda
}

\section{Ni Luh Putu Purhita Pebriani1* ${ }^{*}$ I Gusti Ngurah Japa ${ }^{2}$, Putu Aditya Antara ${ }^{3}$}

1,2,3 Jurusan Pendidikan Dasar, Universitas Pendidikan Ganesha, Singaraja, Indonesia

\section{A R T I C L E I N F O}

Article history:

Received August 01, 2021

Revised August 15, 2021

Accepted September 30, 2021

Available online October 25, 2021

Kata Kunci:

Video Pembelajaran,

Youtube, Perubahan Wujud Benda

\section{Keywords:}

Learning Videos, Youtube,

Changing the Shape of Objects

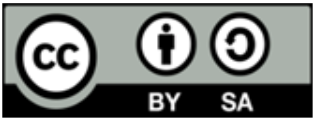

This is an open access article under the CC BY-SA license.

Copyright $(2021$ by Author. Published by Universitas Pendidikan Ganesha.

\begin{abstract}
A B S T R A K
Kurangnya penggunaan media pembelajaran dalam pembelajaran membuat siswa kurang antusias dalam mengikuti pembelajaran. Dalam pembelajaran siswa juga memerlukan media pembelajaran yang dapat membatu memahami materi secara berulang-ulang sehingga diperlukan adanya pengembangan media pembelajaran seperti video. Penelitian ini bertujuan untuk menghasilkan video pembelajaran berbantuan youtube pada muatan IPA materi perubahan wujud benda kelas V SD yang sudah teruji validitas dan reliabilitasnya. Penelitian ini merupakan penelitian pengembangan dengan menggunakan model ADDIE. Subjek pada penelitian ini yaitu: 2 orang ahli materi mata pelajaran IPA, 2 orang ahli media video pembelajaran, 2 orang praktisi dan 12 orang respon siswa. Metode pengumpulan data menggunakan instrumen berupa rating scale dengan lembar penilaian validitas video pembelajaran berbantuan youtube muatan IPA. Teknik analisis data yang digunakan ialah analisis kualitatif dan analisis kuantitatif. Data dianalisis menggunakan rumus mean untuk memperoleh rata-rata skor. Rata-rata skor dari ahli materi yaitu 4,6, ahli media 4,72, respon praktisi 4,66, dan respon siswa 4,61 dengan kualifikasi keseluruhan "sangat baik" dan uji reliabilitas memperoleh hasil dari ahli materi yaitu $98,6 \%$, ahli media $96,3 \%$, praktisi $92,9 \%$ dan respon siswa $92,5 \%$ dengan kualifikasi keseluruhan "sangat tinggi". Penelitian ini menghasilkan video pembelajaran berbantuan youtube pada muatan IPA materi perubahan wujud benda yang sudah teruji validitas dan reliabilitasnya sehingga layak digunakan dalam proses pembelajaran.
\end{abstract}

\section{A B S T R A C T}

The lack of use of learning media in learning makes students less enthusiastic in participating in learning. In learning students also need learning media that can help understand the material repeatedly so that it is necessary to develop learning media such as videos. This study aims to produce a youtube-assisted learning video on the science content of the material for changing the shape of objects in grade 5 elementary schools that have been tested for validity and reliability. This research is development research using the ADDIE model. The subjects in this study were: 2 science subject matter experts, 2 learning video media experts, 2 practitioners and 12 student responses. The data collection method uses an instrument in the form of a rating scale with an assessment sheet for the validity of the YouTube-assisted learning video for science content. The data analysis technique used is qualitative analysis and quantitative analysis. The data were analyzed using the mean formula to obtain the average score. The average score of material experts is 4.6, media experts are 4.72, practitioner responses are 4.66, and student responses are 4.61 with an overall qualification of "very good" and the reliability test obtained results from material experts, namely $98.6 \%$, media experts $96.3 \%$, practitioners $92.9 \%$ and student responses $92.5 \%$ with an overall qualification of "very high". This research produces a youtube-assisted learning video on the science content of the material for changing the shape of objects that have been tested for validity and reliability so that they are suitable for use in the learning process.

\section{PENDAHULUAN}

Pandemic Covid-19 telah mempengaruhi banyak aspek dalam kehidupan manusia termasuk pada pendidikan (Abdusshomad, 2020; Firmansyah \& Kardina, 2020). Di tengah pandemic covid-19, pendidikan harus tetap dilaksanakan meskipun dilaksanakan dengan berjauhan atau tidak tatap muka (Argaheni, 2020; Suhendro, 2020). Pendidikan di Indonesia dengan adanya pandemic covid-19 membuat pemerintah mengeluarkan surat 
edaran untuk melaksanakan pendidikan jarak jauh (Harisuddin, 2021; Megawanti et al., 2020). Pendidikan jarak jauh dilaksanakan dengan cara melaksanakan pembelajaran daring (Susanti, 2020). Pembelajaran daring merupakan suatu konsep pelaksanaan pembelajaran yang dilaksanakan dengan bantuan teknologi dan jaringan internet (Atiqoh, 2020; Bestiantono et al., 2020). Dengan pembelajaran daring tersebut diharapkan akan tetap memberikan kesan yang sama dengan pembelajaran tatap muka kepada siswa (Fitriyani et al., 2020). Keberhasilan pelaksanaan pembelajaran daring terlihat apabila dalam pembelajaran daring dapat mencapai tujuan pembelajaran yang sama dengan pembelajaran tatap muka (Damayanthi, 2020). Dalam pelaksananaan pembelajaran daring, guru memegang peran penting untuk merancang pembelajaran daring yang tidak memberatkan siswa (Chusna \& Utami, 2020; Fajriana \& Safriana, 2021). Hal tersebut dikarenakan, dalam pelaksanaan pembelajaran daring siswa mempersiapkan dan melaksanakan pembelajaran daring secara mandiri (Purwatiningsih \& Soelistyowati, 2021). Berkaitan dengan itu, maka dalam pembelajaran daring sangat diperlukan adanya media pembelajaran yang sesuai agar dapat membatu siswa dalam mengikuti pembelajaran daring dan tidak memberatkan siswa (Sakiah \& Effendi, 2021). Secara umum media pembelajaran dapat dipahami sebagai alat, benda, atau apapun itu yang dapat digunakan dalam proses pembelajaran yang membatu guru dan siswa dalam pelajaran tersebut (Aghni, 2018; Hibra et al., 2019). Penggunaan media pembelajaran dalam pembelajaran daring dapat digunakan untuk merangsang pikiran, perasaan, perhatian dan kemampuan siswa dalam belajar sehingga dapat mendorong terjadiya proses belajar yang baik (Tafonao, 2018). Melihat hal tersebut, adanya media pembelajaran dalam pembelajaran daring sangatlah penting dikarenakan dengan adanya media pembelajaran dapat menciptakan suasana belajar yang menarik bagi siswa sehingga proses pembelajaran tidak terkesan monoton.

Namun pada kenyataannya, pada saat guru melaksanakan pembelajaran tatap muka hanya menggunakan buku guru dan buku siswa saja dengan metode ceramah (Pamungkas et al., 2020; Sari et al., 2018). Begitu pula dengan guru yang melaksnakan pembelajaran daring kurang menggunakan media pembelajaran yang dapat mendukung jalannya pembelajaran (Fitra et al., 2020; Syah \& Tasrif, 2021). Hal tersebut serupa dengan hasil yang didapat pada hasil observasi dimana dalam pembelajaran daring guru hanya mengirimkan materi yang ada di buku siswa kepada siswa untuk dipelajari secara mandiri oleh siswa. Apabila hal tersebut tidak diperbaiki akan berdampak pada siswa. Siswa akan merasa tidak termotivasi dalam mengikuti pembelajaran yang diakibatkan karena pembelajaran yang monoton (Adim et al., 2020; Pawicara \& Conilie, 2020). Selain itu, siswa akan merasa kesulitan dalam memahami materi yang guru berikan karena tidak dijelaskan secara langsung oleh guru. Berkaitan dengan permasalahan tersebut, sangat penting untuk adanya penelitian pengembangan mengenai media pembelajaran yang dapat meningkatkan motivasi belajar siswa dan membantu siswa dalam memahami materi dalam pembelajaran daring. Dengan adanya permasalahan tersebut, maka solusi yang dapat diambil untuk permasalahan tersebut adalah menggunakan media pembelajaran yang sesuai dengan karakteristik siswa, dapat membatu siswa dalam memahami materi dan dapat digunakan dalam pembelajaran daring (Rahmawati et al., 2021). Salah satu media pembelajaran yang dapat dikembangkan adalah media pembelajaran seperti video. Video merupakan salah satu media pembelajaran yang menampilkan gerak, gambar, suara, dan teks yang dikemas dengan singkat, padat dan jelas (Purwanto \& Rizki, 2015; Warju et al., 2020). Pada dasarnya, video menampilakan suara yang dilengkapi dengan materi yang dikemas dalam bentuk teks dan gambar yang terkadang tidak bergerak. Video pembelajaran dapat digunakan dengan baik apabila video tersebut dapat menarik perhatian siswa pada materi yang disampiakan. Telah banyak penelitian yang membahas mengenai kelayakan media video pembelajaran digunakan dalam pembelajaran. Video pembelajaran yang telah dikembangkan sebelumnya dapat dinyatakan bahwa media video pembelajaran valid dan layak digunakan dalam pembelajaran (Anugerah et al., 2020) dan dapat meningkatkan minat belajar siswa (Yuanta, 2020). Berdasarkan hal tersebut maka dapat diyakini bahwa dengan menggunakan media video pembelajaran dapat menjadi solusi dalam permasalahan pembelajaran daring yang telah disebutkan.

Melihat dari hasil penelitian sebelumnya, pengembangan media video pembelajaran hanya dikembangkan untuk satu atau beberapa sekolah dengan cakupan materi yang masih sempit. Pada penelitian pengembangan ini, media video pembelajaran akan dikembangkan dengan basis pada aplikasi youtube. Pemilihan basis tersebut dimaksudkan karena adanya permasalahan siswa yang kurang mampu memahami materi pelajaran yang hanya sekali melihat atau menyimak (Kim, 2020; Widodo et al., 2020). Dengan basis aplikasi youtube tersebut dihapkan dapat membantu siswa dalam memahami materi yang dibelajarkan secara berulang-ulang kapanpun siswa berminat untuk memahami materi tersebut (Dyah Kusuma et al., 2018; Udjaja et al., 2018). Implikasi dalam penelitian ini yaitu video pembelajaran berbantuan youtube muatan IPA merupakan video pembelajaran yang dapat membantu tercapainya proses pembelajaran dan dapat diakses dimana saja dan kapan saja. Selain itu dengan dikembangkannya video pembelajaran berbantuan youtube pada muatan IPA menambah daya tarik dan antusias siswa dalam belajar baik dalam menerima maupun memahami materi pembelajaran, karena di dalam video pembelajaran berisikan materi berupa teks, gambar, suara, animasi, musik dan video di dalam video pembelajaran. Dengan adanya video pembelajaran berbantuan youtube pada muatan IPA materi perubahan wujud benda dapat memotivasi siswa dalam belajar sehinga tujuan pembelajaran dapat terlaksana dan berpengaruh baik dalam hasil belajar. Tujuan penelitian ini adalah untuk menghasilkan media 
video pembelajaran berbantuan youtube yang telah dinyatakan valid dan reliabel. Dengan video pembelajaran yang dinyatakan valid maka dapat dinyatakan bahwa media video pembelajaran dapat dinyatakan layak digunakan dalam pembelajaran. Selain itu, dengan video pembelajaran dinyatakan reliabael maka nantinya media video pembelajaran dapat digunakan terus menerus dan dapat menghasilkan dampak yang sama kepada siswa.

\section{METODE}

Penelitian ini menggunakan model ADDIE. Model ADDIE merupakan model pembelajaran yang sistematis dan tersusun berdasarkan karakteristik siswa. Adapun tahapan-tahapan penelitian dengan model ADDIE yang terdiri atas analisis (analyze), perancangan (design), pengembangan (development), implementasi (implementation), dan evaluasi (evaluation) (Tegeh \& Kirana, 2010). Kelima tahapan-tahapan ini saling berkaitan dan berhubungan satu sama lain. Tahap analisis merupakan tahapan pengumpulan data awal yang digunakan untuk membantu dalam penelitian dan akan digunakan ke tahapan selanjutnya. Setelah tahap analisis dilanjutkan ke tahap perancangan dimana pada tahap ini produk yang dikembangkan diracang untuk dilanjutkan ke tahap pengembangan. Tahap selanjutnya tahap pengembangan dimana pada tahapini produk dibuat dan diuji validitas serta reliabilitasnya. Selanjutnya tahap implementasi yang dimana tahap ini produk yang dikembangkan diplementasikan kepada siswa. Tahap evaluasi merupakan tahapan terakhir pada penelitian ini yang dimana pada tahap ini akan dievaluasi semua hasil yang telah diperoleh. Pada penelitian ini hanya sampai pada tahap pengembangan saja. Berikut tahapan model ADDIE disajikan pada Gambar 1.

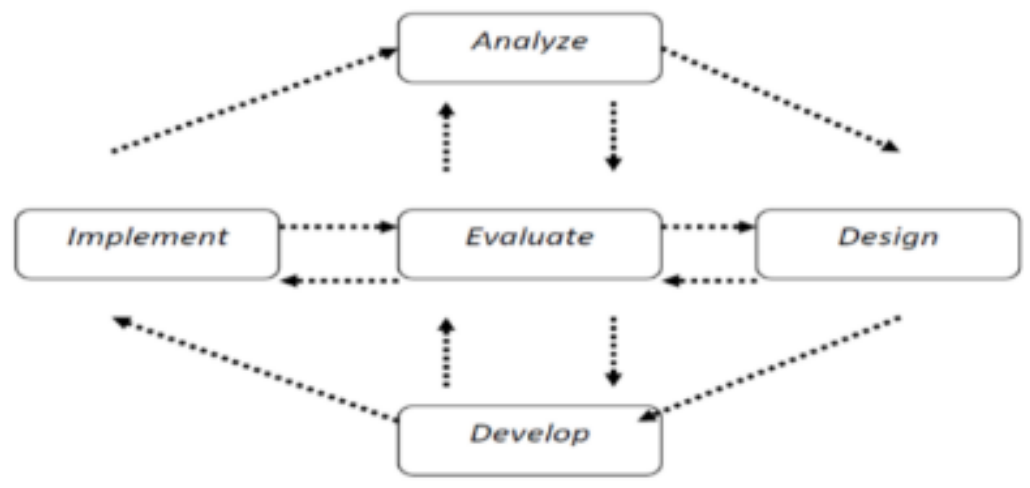

Gambar 1 Model Pengembangan ADDIE

Subjek dalam penelitian ini yaitu beberapa ahli, yaitu 2 orang dosen ahli materi, 2 orang dosen ahli media, 2 orang guru respon praktisi dan 12 orang siswa kelas $\mathrm{V}$ sekolah dasar. Ahli materi merupakan dosen fakultas ilmu pendidikan, Undiksha yang memiliki kompetensi pada bidang materi muatan IPA. Ahli media merupakan dosen fakultas ilmu pendidikan, Undiksha yang memiliki kompetensi pada bidang media pembelajaran. Guru sebagai praktisi merupakan guru sekolah dasar kelas V dengan setrata 1. Siswa yang menjadi subjek dalam penelitian merupakan siswa yang sedang duduk di jenjang sekolah dasar kelas V. Metode pengumpulan data adalah cara peneliti untuk mengumpulkan data dari hasil yang telah diteliti. Adapun metode pengumpulan data yang dipilih peneliti, adalah wawancara dan kuesioner. Kuesioner (angket) merupakan pengumpulan data yang diberikan kepada responden yang berisikan pertanyaan. Wawancara adalah kegiatan yang dilakukan untuk mengumpulkan data dengan bertanya langsung ke narasumber. Instrumen yang digunakan dalam penelitian ini menggunakan instrumen rating scale. Instrumen rating scale adalah alat yang digunakan untuk memperoleh data dari lembar penilaian yang diuji oleh para ahli. Kisi-kisi lebih lengkap ditunjukkan pada Table 1.

Tabel 1. Kisi-Kisi Instrumen penelitian

\begin{tabular}{ll}
\hline \multicolumn{1}{c}{ Aspek } & \multicolumn{1}{c}{ Indikator } \\
\hline Penggunaan Bahasa & Kejelasan penggunaan Bahasa \\
& Kejelasan penyusunan kata dan kalimat \\
Pembelajaran & Kesesuaian materi dengan kompetensi yang ingin dicapai \\
& Kesesuaian materi dengan indikator yang ingin dicapai \\
& Pemberian latihan \\
\hline
\end{tabular}

\begin{tabular}{ll}
\hline Kisi-Kisi Instrumen Ahli Media & \\
\hline Teks dan Gambar & Kejelasan teks yang ditampilkan \\
& Kejelasan gambar yang ditampilkan
\end{tabular}




\begin{tabular}{ll}
\hline \multicolumn{1}{c}{ Aspek } & \multicolumn{1}{c}{ Indikator } \\
\hline Materi & Ketepatan warna teks dan gambar \\
& Ketepatan materi \\
Daya Tarik & Kejelasan materi dalam media \\
Kemudahan Penggunaan & Kemenarikan penampilan media \\
Penggunaan Bahasa & Kemudahan penggunaan media \\
& Kejelasan penggunaan Bahasa \\
& Kejelasan penggunaan kata \\
\hline Kisi-Kisi Instrumen Praktisi & Kejelasan penggunaan kalimat \\
\hline Teks dan gambar & Kejelasan teks yang ditampilkan \\
& Kejelasan gambar yang ditampilkan \\
Daya Tarik & Ketepatan warna teks dan gambar \\
Materi & Kemenarikan penampilan media \\
Penggunaan Bahasa & Ketepatan materi \\
& Kejelasan penggunaan bahasa \\
& Kejelasan penggunaan kata \\
\hline Kisi-Kisi Instrumen Siswa & Kejelasan penggunaan kalimat \\
\hline Materi & Pemilihan materi \\
Kemudahan penggunaan & Kemudahan penggunaan media \\
\hline
\end{tabular}

Agar isi instrumen yang disusun dapat dikatakan valid, maka pengujian validitas instrument dilakukan dengan menggunakan beberapa penilaian ahli/pakar (judges). Validitas isi adalah sejauh mana suatu perangkat tes mencerminkan keseluruhan kemampuan yang diukur yang berupa analisis rasional terhadap domain yang hendak diukur (Hendryadi, 2017). Analisis validitas isi menggunakan rumus Gregory dengan mekanisme pada instrumen yang telah dibuat, pakar/ahli memberikan penilaian tiap butirnya dengan skor 1 atau 2 (tidak relevan), skor 3 atau 4 (relevan), hasil penelitian pakar dibuat dalam bentuk matrik tabulasi $(2 \times 2)$. Setelah memperoleh hasil langkah terakhir yang dilakukan yaitu dengan membandingkan hasil perhitungan koefisien dan validitas isi. Setelah dilakukan uji validasi terhadap instrument penilaian yang digunakan, selanjutnya dilakukan pengujian reabilitas terhadap instrument penilain yang digunakan. Reliabilitas digunakan untuk mengetahui bagaimana ketetapan dan keajegan alat dalam menilai apa yang akan dinilai. Reliabilitas adalah salah satu peran atau karakter utama instrumen pengukuran yang baik dan benar. Butir-butir di instrumen yang telah valid kemudian diuji reliabilitasnya (Wulandari et al., 2019). Adapun uji reliabilitas instrumen dalam penelitian ini menggunakan rumus tingkat percentages of agreements antara kedua ahli yang datanya hanya "ya" atau "tidak" yang terdapat pada lampiran uji instrumen "relevan" dan "tidak relevan". Dari hasil perhitungan yang diperoleh kemudian dibandingkan dengan kriteria reliabilitas instrumen.

Dalam penelitian ini peneliti menggunakan analisis data kuantitatif dan analisis data kualitatif. Analisis kualitatif menekankan pada proses. Proses bagaimana fakta, realita, gejala, peristiwa itu terjadi dan dialami serta data atau informasi yang diperoleh benar-benar berasal dari orang yang mengalami langsung peristiwa itu. Metode analisis deskriptif kualitatif ini digunakan untuk mengolah data hasil (review) dari beberapa ahli materi, media, dan praktisi terhadap video pembelajaran yang dikembangkan peneliti. Metode analisis statistik deskriptif kuantitatif yang berupa angka atau persentase mengenai objek yang diteliti (Agung, 2014). Analisis deskriptif kuantitatif digunakan dalam mengolah data berupa angka-angka atau nilai yang diperoleh melalui lembar penilaian. Analisis deskriptif kuantitatif digunakan sebagai alat pengolah data yang berbentuk angka atau skor. Untuk mengetahui validitas suatu produk yang dkembangkan skor yang diperoleh kemudian dihitung rataratanya menggunakan rumus mean. Apabila rata-rata skor telah diperoleh, kemudian dikonversikan dengan menggunakan pedoman konversi skala lima untuk mengetahui validitas video pembelajaran yang telah dikembangkan.

\section{HASIL DAN PEMBAHASAN}

Hasil

Video pembelajaran berbantuan youtube muatan IPA materi perubahan wujud benda kelas V SD Tahun Ajaran 2020/2021 dikembangkan dengan menggunakan model ADDIE yang terdapat tahapan-tahapan didalamnya. Adapun 5 tahapan dari model ADDIE yaitu, analisis (analyze), perancangan (design), pengembangan (development), implementasi (implementation), dan evaluasi (evaluation). Kelima tahapan-tahapan ini saling berkaitan dan berhubungan satu sama lain. Namun karena keterbatasan waktu, situasi dan kondisi, maka tahap implementasi dan evaluasi tidak dilaksanakan. Tahap analisis dilakukan dengan analisis kebutuhan, analisis kurikulum dan analisis karakteristik siswa. Pada analisis kebutuhan bahwa diketahui permasalahan yaitu 
kurangnya media pembelajaran yang bervariasi pada pembelajaran daring sehingga menimbulkan daya tarik siswa dalam belajar berkurang. Pada analisis karakteristik siswa menunjukkan bahwa siswa SD masih dalam kisaran usia 6-12 tahun yang dimana masih dalam tahap operasional konkret. Tahap ini siswa belum bisa memahami pembelajaran tanpa menggunakan alat bantu yang menarik yang dapat menunjang proses pembelajaran. Maka dari itu diperlukannya media pembelajaran sebagai alat bantu yang menunjang proses pembelajaran dalam penyampaian materi. Data yang telah diperoleh pada tahap ini dikumpulkan untuk menjadi acuan dalam proses pengembangan media. Pada analisis kurikulum menunjukkan bahwa pada muatan IPA materi Perubahan Wujud Benda yang terdapat pada Tema 7 Subtema 1 Kelas V mencakup materi sifat-sifat benda cair, padat dan gas serta perubahan wujud benda cair, padat dan gas.

Tahap perancangan merupakan tahapan perancangan dari produk yang dikembangkan berdasarkan hasil analisis yang telah dikumpulkan. Tahap ini dilakukan dengan menyusun empat instrumen penilaian terhadap video pembelajaran berbantuan youtube muatan IPA yang terdiri dari instrumen validasi ahli materi, instrumen validasi ahli media, instrumen validasi respon praktisi dan instrumen respon siswa. Dari keempat instrumen tersebut telah dilakukan uji validitas isi dan reliabilitas instrumen. Validasi isi instrumen memperoleh hasil yang berada pada rentangan 0,80-1,00 sehingga instrumen penilaian video pembelajaran berbantuan youtube muatan IPA dinyatakan valid dengan tingkat validitas isi "sangat tinggi". Selain itu, dilakukan perancangan isi yang terdapat didalam video pembelajaran dengan menggunakan bantuan storyborad. Aplikasi yang digunakan yaitu kinemaster dan pengeditan serta perekaman suara dilakukan melalui handphone. Video pembelajaran ini berdurasi 14.44 menit dan video latihan soal berdurasi 01.14 menit. Pada tahap ini peneliti membuat rancangan video pembelajaran yang tediri dari opening, inti, dan closing. Di dalam video pembelajaran yang dirancang terdapat 3 jenis musik latar yang berbeda-beda. Pada slide pertama dengan latar musik Natalie Taylor-Surrender (lirik), kemudian pada slide berikutnya dan seterusnya dengan latar musik Ikson-Alive (Official) dan Ikson-Fresh (Official) secara bergantian. Diberikannya musik pada latar video pembelajaran guna menambah daya tarik siswa dalam menyimak video pembelajaran. Video pembelajaran yang dirancang memiliki resolusi sebesar 720p dengan rasio 16:9. Terdapat satu talent yang berfungsi sebagai narator dalam mengisi suara dalam video pembelajaran yang dirancang ini. Selanjutnya ketika rancangan video pembelajaran telah dibuat, kemudian dikonsultasikan dengan dosen pembimbing I dan II guna memperoleh hasil maksimal video pembelajaran yang dikembangkan. Setelah rancangan video pembelajaran disetuji oleh dosen pembimbing, kemudian penelitian tersebut dapat dilanjutkan ketahap pengembangan. Rancangan media video pembelajaran yang dikembangkan ditunjukkan pada gambar 2 .

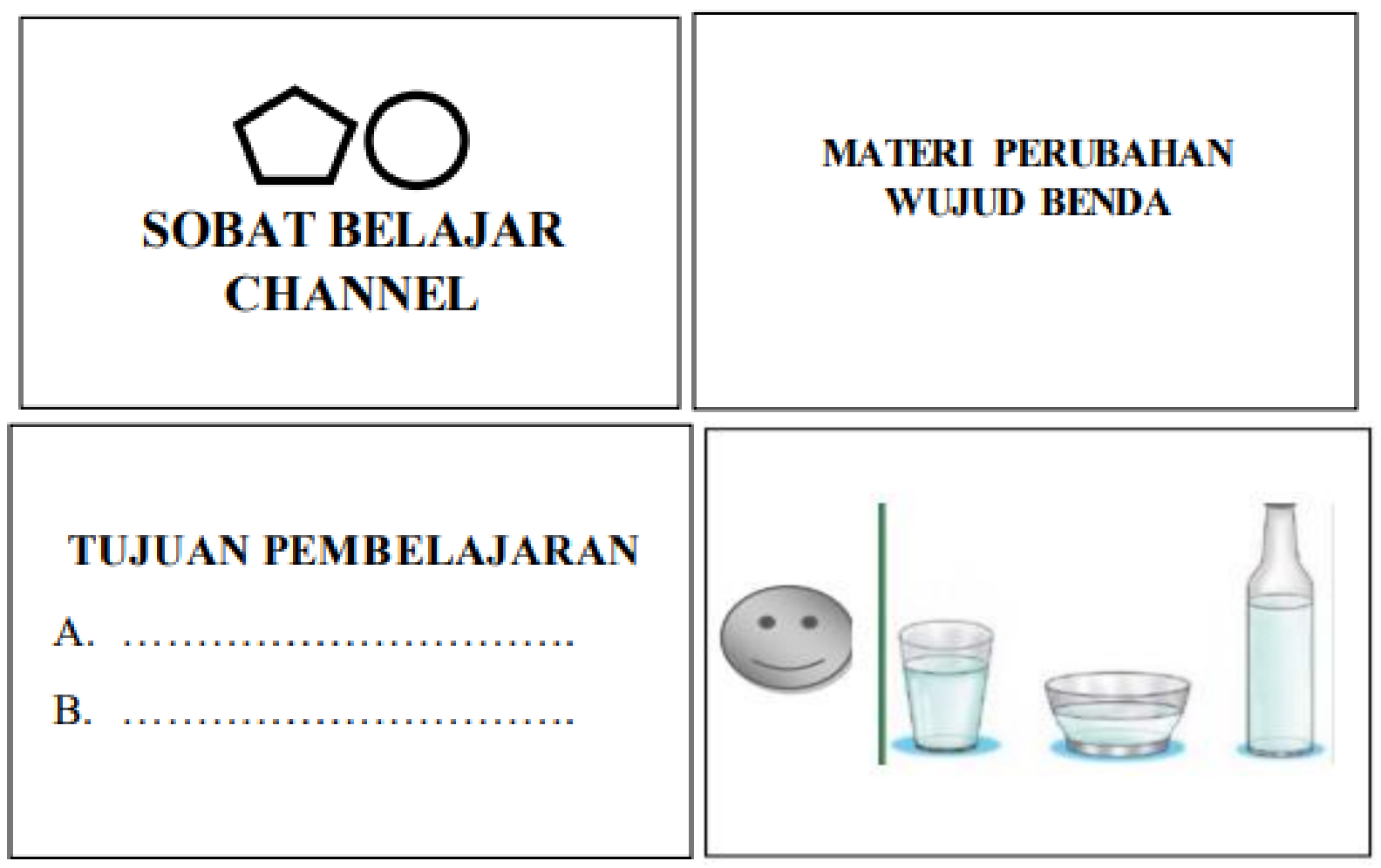



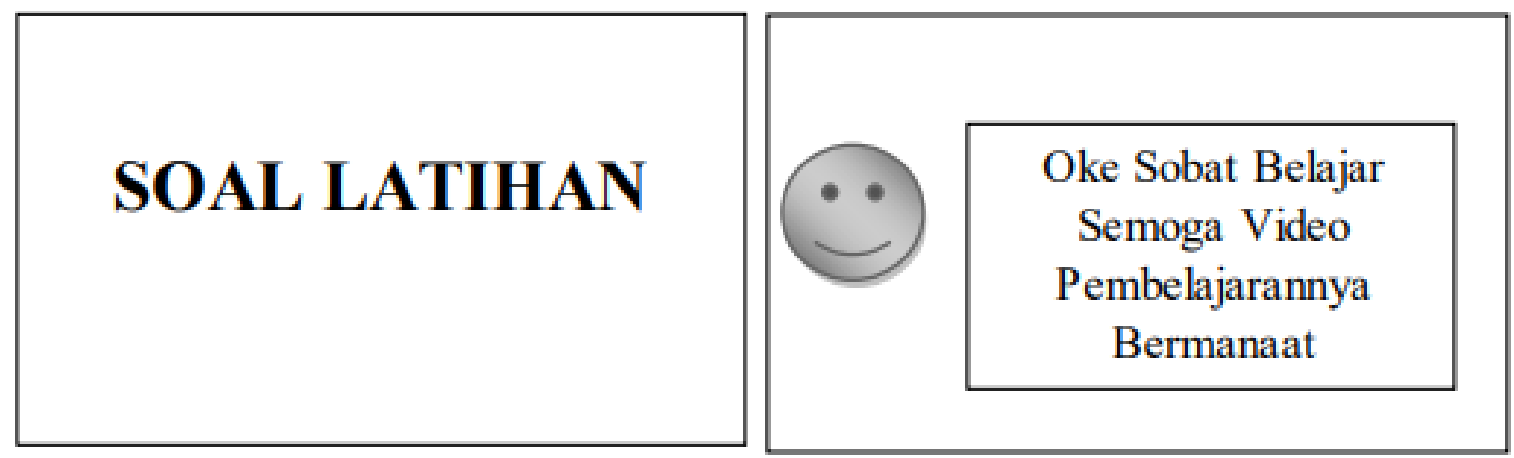

Gambar 2. Rancangan media video pembelajaran

Tahap pengembangan (development). Pada tahap ini dilaksanakan pengembangan produk yaitu video pembelajaran berbantuan youtube muatan IPA. Pengembangan video pembelajaran berbantuan youtube muatan IPA dilakukan sesuai dengan rancangan produk yang telah disetuji oleh dosen pembimbing. Adapun hasil pengembangan produk yang telah dilakukan tersaji pada gambar 2 .
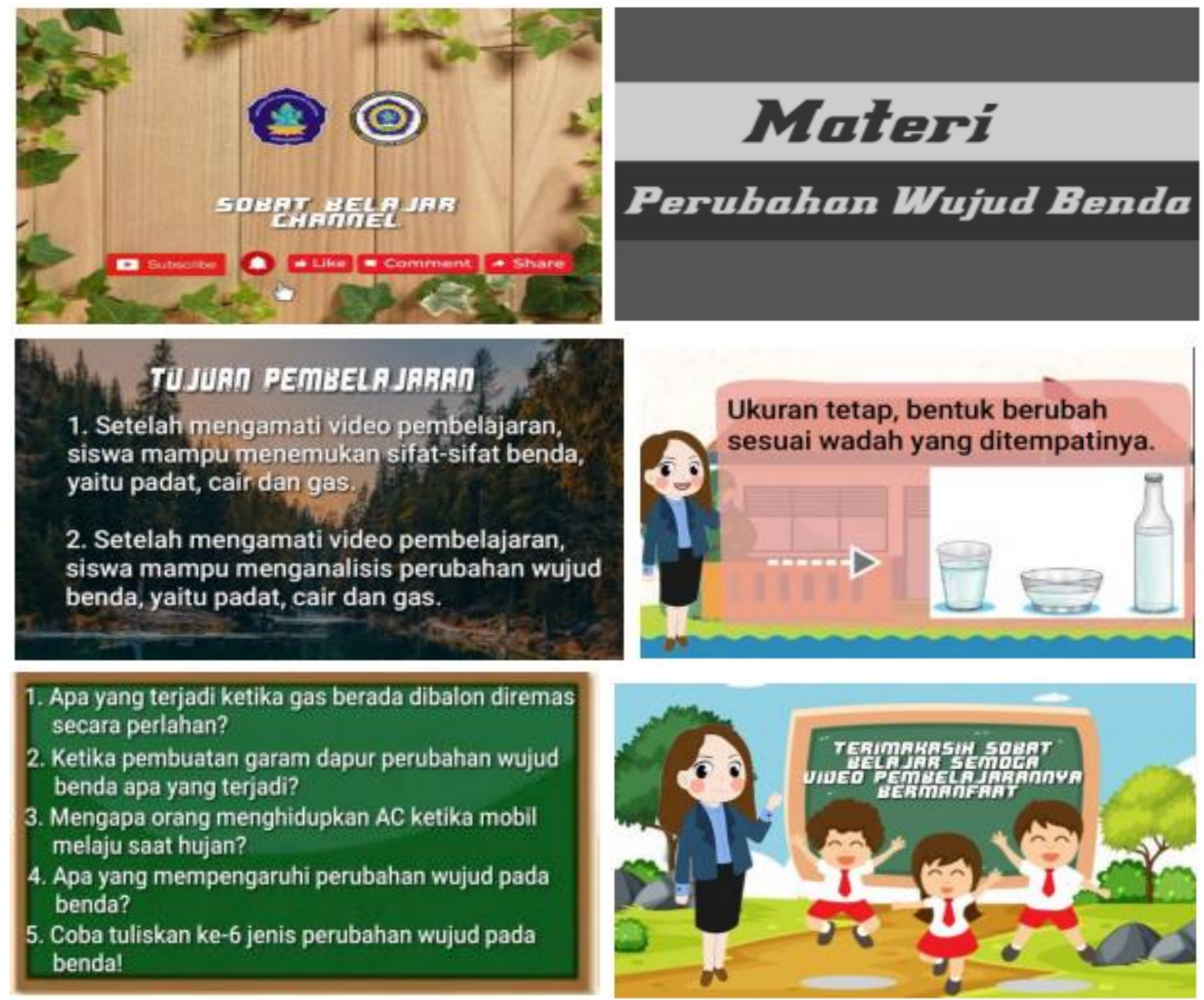

Gambar 3. hasil pengembangan produk

Setelah video pembelajaran dikembangkan, kemudian video pembelajaran berbantuan youtube muatan IPA dapat diuji validitasnya, karena syarat dari layaknya suatu produk dapat dilihat dari uji validitas dan reliabilitasnya. Uji validitas produk dilaksanakan melalui kegiatan review oleh beberapa ahli, yaitu 2 orang dosen ahli materi, 2 orang dosen ahli media dan 2 orang guru respon praktisi. Kegiatan review ini dilakukan untuk mengetahui kekurangan dari produk yang dikembangkan melalui masukan, saran dan komentar. Adapun 
rata-rata skor yang didapatkan dari uji validitas oleh para ahli, yaitu ahli materi memperoleh rata-rata 4,6 apabila dikonversikan kedalam tabel skala lima berada pada rentangan skor 4,0<X $\leq 5,0$ dengan kualifikasi "sangat baik". Ahli media memperoleh rata-rata 4,72 dan apabila dikonversikan kedalam tabel skala lima berada pada rentangan skor 4,0<X $\leq 5,0$ dengan kualifikasi "sangat baik". Respon praktisi memperoleh rata-rata 4,66 dan apabila dikonversikan kedalam tabel skala lima berada pada rentangan skor 4,0<X $\leq 5,0$ dengan kualifikasi "sangat baik". Respon siswa memperoleh rata-rata 4,61 dan apabila dikonversikan kedalam tabel skala lima berada pada rentangan skor 4,0<X $\leq 5,0$ dengan kualifikasi "sangat baik". Hasil yang didapatkan dari uji reliabilitas, yaitu ahli materi memperoleh hasil 98,6\% apabila dikonversikan kedalam kriteria derajat reliabilitas berada pada rentangan 81-100\% dengan kualifikasi "sangat tinggi". Ahli media memperoleh hasil 96,3\% apabila dikonversikan kedalam kriteria derajat reliabilitas berada pada rentangan $81-100 \%$ dengan kualifikasi "sangat tinggi". Respon praktisi memperoleh hasil 92,3\% apabila dikonversikan kedalam kriteria derajat reliabilitas berada pada rentangan 81-100\% dengan kualifikasi "sangat tinggi". Respon siswa memperoleh hasil 92,5\% apabila dikonversikan kedalam kriteria derajat reliabilitas berada pada rentangan 81-100\% dengan kualifikasi "sangat tinggi".

\section{Pembahasan}

Penelitian pengembangan ini menghasilkan produk video pembelajaran berbantuan youtube muatan IPA materi Perubahan Wujud Benda Kelas V SD Tahun Ajaran 2020/2021. Video yang dikembangkan dalam penelitian ini adalah video pembelajaran berbantuan youtube, maksudnya adalah video yang dikembangkan kemudian diupload didalam aplikasi layanan google yaitu youtube. Ciri khas dalam video pembelajaran berbantuan youtube ini adalah dapat ditonton berulang kali dimana saja dan kapan saja. Produk yang dikembangkan telah dinyatakan valid dan reliabel berdasarkan hasil validitas dan uji reabilitas dari uji ahli materi, uji ahli media, respon praktisi dan respon siswa. Tahap analisis dilakukan dengan analisis kebutuhan, analisis kurikulum dan analisis karakteristik siswa. Berdasarkan hasil analisis kebutuhan diketahui permasalahan dalam pelaksanaan pembelajaran guru kurang menggunakan media pembelajaran yang disebabkan keterbatasan media pembelajaran yang ada. Hasil analisis kurikulum menunjukkan bahwa kertersediaan media pembelajaran pada muatan IPA materi Perubahan Wujud Benda yang terdapat pada Tema 7 Subtema 1 Kelas V masih kurang. Hasil analisis karakteristik siswa menunjukkan bahwa siswa kelas V SD berada pada tahap oprasional kongkrit (Hardani \& Akmal, 2017; Maryani \& Sumiar, 2018). Siswa yang berada pada tahap oprasional kongkrit sangat memerlukan adanya media pembelajaran untuk membantu siswa dalam memahami materi pembelajaran(Saputri et al., 2018; Sukmanasa et al., 2017). Dengan menggunakan media yang dapat memberikan penjelasan kepada siswa secara kongkrit akan memudahkan siswa dalam memahami materi (Asmara et al., 2018; Hilmy \& Niam, 2020). Hasil yang telah diperoleh menjadi acuan dalam pengembangan media.

Tahap perancangan dilakukan dengan menyusun empat instrumen penilaian terhadap video pembelajaran berbantuan youtube muatan IPA yang terdiri dari instrumen validasi ahli materi, instrumen validasi ahli media, instrumen validasi respon praktisi dan instrumen respon siswa. Dari keempat instrumen tersebut telah dilakukan uji validitas isi dan reliabilitas instrumen. Tahap perancangan dilakukan perencanaan media video pembelajaran yang menggunakan aplikasi kinemaster dan pengeditan serta perekaman suara dilakukan melalui handphone. Video pembelajaran ini berdurasi 14.44 menit dan video latihan soal berdurasi 01.14 menit. Pada tahap ini peneliti membuat rancangan video pembelajaran yang tediri dari opening, inti, dan closing. Di dalam video pembelajaran yang dirancang terdapat 3 jenis musik latar yang berbeda-beda. Pada slide pertama dengan latar musik Natalie Taylor-Surrender (lirik), kemudian pada slide berikutnya dan seterusnya dengan latar musik Ikson-Alive (Official) dan Ikson-Fresh (Official) secara bergantian. Diberikannya musik pada latar video pembelajaran guna menambah daya tarik siswa dalam menyimak video pembelajaran. Video pembelajaran yang dirancang memiliki resolusi sebesar 720p dengan rasio 16:9. Terdapat satu talent yang berfungsi sebagai narator dalam mengisi suara dalam video pembelajaran yang dirancang ini. Dengan dikembangkan media video yang didesain dengan gambar yang ditambah dengan unsur musir yang menarik serta adanya narator dapat meningkatkan minat siswa dalam mengikuti pembelajaran sehingga permasalahan yang disebutkan diatas dapat dipecahkan (Istuningsih et al., 2018; Saputri et al., 2018).

Tahap pengembangan yang dilakukan untuk membuat media yang telah dirancang sebelumnya menjadi media sesungguhnya dan telah teruji validitanya. Media yang telah dibuat kemudian dilakukan uji validasi yang dilakukan oleh 2 orang ahli media, 2 orang ahli materi, 2 orang guru atau praktisi, dan 12 orang siswa. Berdasarkan hasil validitas dan reabilitas dari uji ahli materi, uji ahli media, respon praktisi dan respon siswa terhadap pengembangan video pembelajaran berbantuan youtube muatan IPA dinyatakan layak. Kelayakan media video pembelajaran yang dikembangakan dapat dilihat dari aspek kesesuaian dengan karakteristik siswa, aspek desain media, dan aspek penggunaan. Ditinjau dari aspek kesesuaian dengan karakteristik siswa, media video pembelajaran dikembangkan dengan didadasarkan pada karakteristik siswa SD kelas $\mathrm{V}$ yang masih berdasar pada tahap operasional konkrit. Penggunaan media pembelajaran yang sesuai 
dengan karakteristik siswa dalam pembelajaran dapat membantu siswa dalam memahami suatu materi yang bersifat abstrak dan mampu meningkatkan hasil maupun prestasi belajar siswa (Ekayani, 2017; Novita et al., 2019). Hal tersebut sejalan dengan teori Piaget yang menyebutkan bahwa anak sekolah dasar berada pada tahap oprasional kongkrit yang menandakan bahwa anak akan mengerti jika diajar dengan benda kongkrit atau nyata (AD, 2018; Bujuri, 2018). Kelayakan media video pembelajaran juga dapat ditinjau dari aspek desain media yang menampilkan materi yang bersifat abstrak yang disajikan dalam bentuk animasi sehingga dapat menarik minat siswa dalam belajar. Dengan menampilkan animasi pada proses pembelajaran akan memberikan kesan menarik bagi siswa sehingga dapat membuat pembelajaran yang aktif, kreatif, menyenangkan, dan efektif (Novita et al., 2019; Panjaitan et al., 2020). Dengan adanya media video pembelajaran dapat memberikan kesan belajar ideal, bermakna dan menyenangkan (Andrian, 2017). Dengan hal tersebut, media video pembelajaran dapat dikatakan layak digunakan dalam suatu proses pembelajaran karena dapat menarik minat siswa dalam belajar sehingga memunculkan kesan pembelajaran yang ideal, bermakna, dan menyenangkan. Kelayakan media video pembelajaran juga dapat ditinjau dari apek penggunaan, dimana media video pembelajaran didesain agar dapat diakses melalui media youtube sehingga dapat ditontong secara berulang-ulang oleh siswa. Video yang dapat ditonton secara berulang-ulang oleh siswa dapat memudahkan siswa dalam memahami materi dengan lebih baik karena siswa dapat memutar ulang penyampaian materi pada video (Fedistia \& Musdi, 2020; Hamid \& Effendi, 2019).

Berdasarkan hasil yang telah diperoleh relevan dengan penelitian yang telah dilakukan sebelumnya mengenai media video pembelajaran. Penelitian yang mendapatkan hasil bahwa media video pembelajaran yang dikembangkan dinyatakan sangat layak digunakan dalam proses pembelajaran (Suratun et al., 2018). Selain itu, penelitian yang mendapatkan hasil bahwa media video pembelajaran dengan animasi dinyatakan valid dan layak digunakan dalam proses pembelajaran (Kafah et al., 2020). Penelitian lainnya yang mendapatkan hasil bahwa media video pembelajaran yang dikembangkan dengan berbasis youtube dinyatakan valid dan sangat layak digunakan dalam pembelajaran dan penelitian selanjutnya (Yudela et al., 2020). Implikasi dalam penelitian ini yaitu video pembelajaran berbantuan youtube muatan IPA merupakan video pembelajaran yang dapat membantu tercapainya proses pembelajaran dan dapat diakses dimana saja dan kapan saja. Selain itu dengan dikembangkannya video pembelajaran berbantuan youtube pada muatan IPA menambah daya tarik dan antusias siswa dalam belajar baik dalam menerima maupun memahami materi pembelajaran, karena di dalam video pembelajaran berisikan materi berupa teks, gambar, suara, animasi, musik dan video di dalam video pembelajaran. Dengan adanya video pembelajaran berbantuan youtube pada muatan IPA materi perubahan wujud benda dapat memotivasi siswa dalam belajar sehinga tujuan pembelajaran dapat terlaksana dan berpengaruh baik dalam hasil belajar.

Adapun kelebihan dari video pembelajaran berbantuan youtube pada muatan IPA yaitu video berisikan materi berupa teks, gambar, suara, animasi, musik dan video di dalam video pembelajaran, dan dapat diakses dimana saja dan kapan saja. Dengan menggunakan media pembelajaran berbantuan youtube ini juga dapat meningkatkan minat siswa dalam mengikuti pembelajaran dikarenakan media video pembelajaran dapat membuat kesan pembelajaran yang menarik agi siswa (Akmal et al., 2020; Pham et al., 2020). Adapun kelemahan dari video pembelajaran berbantuan youtube yaitu memerlukan gadged dalam mengakses video pembelajaran dan memerlukan kuota/paket data dalam mengaksesnya. Selain itu, kelemahan media video pembelajaran yang dikembangkan dalam penelitian ini adalah cakupan materi yang dikembangkan masih sempit yaitu hanya terpaku pada muatan IPA materi Perubahan Wujud Benda yang terdapat pada Tema 7 Subtema 1 Kelas V. Berdasarkan kelemahan tersebut, maka diperlukan adanya penelitian yang serupa mengembangkan media video pembelajaran dengan cakupan materi yang lebih luas serta dikembangkan dengan bantuan atau basis lainnya yang lebih baik.

\section{SIMPULAN}

Penelitian pengembangan ini menghasilkan produk video pembelajaran berbantuan youtube muatan IPA materi Perubahan Wujud Benda Kelas V SD Tahun Ajaran 2020/2021. Produk yang dikembangkan telah dinyatakan valid dan reliabel berdasarkan hasil validitas dan uji reabilitas dari uji ahli materi, uji ahli media, respon praktisi dan respon siswa. Berdasarkan hal tersebut maka video pembelajaran layak digunakan dalam proses pembelajaran khususnya pada muatan IPA materi Perubahan Wujud Benda Kelas V SD.

\section{DAFTAR PUSTAKA}

Abdusshomad, A. (2020). Pengaruh Covid-19 terhadap Penerapan Pendidikan Karakter dan Pendidikan Islam. QALAMUNA: Jurnal Pendidikan, Sosial, dan Agama, 12(2), 107-115. https://doi.org/10.37680/qalamuna.v12i2.407.

AD, Y. (2018). Konsep Perkembangan Kognitif Perspektif Al-Ghazali Dan Jean Piaget. KONSELI: Jurnal Bimbingan dan Konseling (E-Journal), 5(2), 97. https://doi.org/10.24042/kons.v5i2.3501. 
Adim, M., Herawati, E. S. B., \& Nuraya, N. (2020). Pengaruh Model Pembelajaran Contextual Teaching and Learning menggunakan Media Kartu terhadap Minat Belajar IPA kelas IV SD. Jurnal Pendidikan Fisika dan Sains, 3(1), 6-12. https://doi.org/https://doi.org/10.52188/jpfs.v3i1.76.

Aghni, R. I. (2018). Fungsi Dan Jenis Media Pembelajaran Dalam Pembelajaran Akuntansi. Jurnal Pendidikan Akuntansi Indonesia, 16(1). https://doi.org/10.21831/jpai.v16i1.20173.

Agung, A. A. G. (2014). Metodologi Penelitian Pendidikan. Deepublish.

Akmal, S., Masna, Y., Tria, M., \& Maulida, T. A. (2020). EFL Teachers' Perceptions: Challenges and Coping Strategies of Integrated Skills Approach (ISA) Implementation at Senior High Schools in Aceh. IJELTAL (Indonesian Journal of English Language Teaching and Applied Linguistics), 4(2), 363. https://doi.org/10.21093/ijeltal.v4i2.522.

Andrian, R. (2017). Pembelajaran Bermakna Berbasis Post It. Jurnal Mudarrisuna. Jurnal Mudarrisuna, 7(1), 103118. https://doi.org/https://doi.org/http://dx.doi.org/10.22373/jm.v7i1.1911.

Anugerah, S., Ulfa, S., \& Husna, A. (2020). Pengembangan Video Pembelajaran Bahasa Isyarat Indonesia (Bisindo) Untuk Siswa Tunarungu Di Sekolah Dasar. JINOTEP (Jurnal Inovasi dan Teknologi Pembelajaran): Kajian dan Riset Dalam Teknologi Pembelajaran, 7(2), 76-85. https://doi.org/10.17977/um031v7i22020p076.

Argaheni, N. B. (2020). Sistematik Review: Dampak Perkuliahan Daring Saat Pandemi COVID-19 Terhadap Mahasiswa Indonesia. PLACENTUM: Jurnal Ilmiah Kesehatan dan Aplikasinya, 8(2), 99. https://doi.org/10.20961/placentum.v8i2.43008.

Asmara, Y. P., Kurniawan, T., Sutjipto, A. G. E., \& Jafar, J. (2018). Application of plants extracts as green corrosion inhibitors for steel in concrete - A review. Indonesian Journal of Science and Technology, 3(2), 158-170. https://doi.org/10.17509/ijost.v3i2.12760.

Atiqoh, L. N. (2020). Respon Orang Tua Terhadap Pembelajaran Daring Pada Masa Pandemi Covid-19. Thufuli : Jurnal Ilmiah Pendidikan Islam Anak Usia Dini, 2(1), 45. https://doi.org/10.33474/thufuli.v2i1.6925.

Bestiantono, D. S., Agustina, P. Z. R., \& Cheng, T.-H. (2020). How Students' Perspectives about Online Learning Amid the COVID-19 Pandemic? Studies in Learning and Teaching, 1(3), 133-139. https://doi.org/10.46627/silet.v1i3.46.

Bujuri, D. A. (2018). Analisis Perkembangan Kognitif Anak Usia Dasar dan Implikasinya dalam Kegiatan Belajar Mengajar. LITERASI (Jurnal Ilmu Pendidikan), 9(1), 37. https://doi.org/10.21927/literasi.2018.9(1).3750.

Chusna, P. A., \& Utami, A. D. M. (2020). Dampak Pandemi Covid-19 Terhadap Peran Orang Tua Dan Guru Dalam Meningkatkan Kualitas Pembelajaran Daring Anak Usia Sekolah Dasar. PREMIERE : Journal of Islamic Elementary Education, 2(1), 11-30. https://doi.org/10.51675/jp.v2i1.84.

Damayanthi, A. (2020). Efektivitas Pembelajaran Daring di Masa Pandemi Covid 19 pada Perguruan Tinggi Keagamaan Katolik. EDUTECH: Jurna Teknologi Pendidikan, 19(3), 189-210. https://doi.org/https://doi.org/10.17509/e.v1i3.26978.

Dyah Kusuma, E., Gunarhadi, G., \& Riyadi, R. (2018). The Development of Problem-Based Quantum Learning Model in Elementary Schoolin. International Journal of Educational Research Review, 3(3), 9-16. https://doi.org/10.24331/ijere.412267.

Ekayani, P. (2017). (2017). Pentingnya Penggunaan Media. Jurnal Fakultas Ilmu Pendidikan Universitas Pendidikan Ganesha Singaraja, 2(1), 1-11. https://www.researchgate.net/publication/315105651.

Fajriana, \& Safriana. (2021). Analisis Kesiapan Guru Fisika dan Matematika dalam Pembelajaran Daring. Jpsi, 9(2), 293-304. https://doi.org/10.24815/jpsi.v9i2.19162.

Fedistia, R., \& Musdi, E. (2020). Efektivitas Perangkat Pembelajaran Berbasis Flipped Classroom untuk Meningkatkan Kemampuan Penalaran Matematis Peserta Didik. Jurnal Didaktik Matematika, 7(1), 4559. https://doi.org/10.24815/jdm.v7i1.14371.

Firmansyah, Y., \& Kardina, F. (2020). Pengaruh New Normal Ditengah Pandemi Covid-19 Terhadap Pengelolahan Sekolah Dan Peserta Didik. Buana Ilmu, 4(2), 99-112. https://doi.org/10.36805/bi.v4i2.1107.

Fitra, A., Sitorus, M., Parulian Sinaga, D. C., \& Marpaung, E. A. P. (2020). Pemanfaatan dan Pengelolaan Google Classroom Sebagai Media Pembelajaran Dan Pengajaran Daring Bagi Guru-Guru SMP. Jurnal Pengabdi, 3(2), 101. https://doi.org/10.26418/jplp2km.v3i2.42387.

Fitriyani, Y., Fauzi, I., \& Sari, M. Z. (2020). Motivasi Belajar Mahasiswa Pada Pembelajaran Daring Selama Pandemik Covid-19. Profesi Pendidikan 121-132. https://doi.org/10.23917/ppd.v7i1.10973.

Hamid, A., \& Effendi, H. (2019). Flipped Classroom sebagai Alternatif Pembelajaran pada Mata Pelajaran Dasar Listrik dan Elektronika. Jurnal Teknik Elektro dan Vokasional, V(1), 81-86. https://doi.org/https://doi.org/10.24036/jtev.v5i1.105414.

Hardani, A. T. A., \& Akmal, A. (2017). Penerapan Metode Snowball Throwing Berbantuan Media Kongkret Untuk Meningkatkan Keaktifan dan Hasil Belajar IPA Siswa Kelas IV Sekolah Dasar. Jurnal Pendidikan Dasar PerKhasa, 3(1), 233-245. https://doi.org/https://doi.org/10.31932/jpdp.v3i1.37. 
Harisuddin, M. I. (2021). Kemampuan Pemecahan Masalah Matematis Dan Kemandirian Belajar Siswa Dengan Pjj Dimasa Covid-19. Teorema: Teori dan Riset Matematika, 6(1), 98. https://doi.org/10.25157/teorema.v6i1.4683.

Hendryadi. (2017). Validitas Isi: Tahap Awal Pengembangan Kuesioner. Jurnal Riset Manajemen dan Bisnis (JRMB) Fakultas Ekonomi UNIAT, 2(2), 169-178. https://doi.org/10.36226/jrmb.v2i2.47.

Hibra, B. Al, Hakim, L., \& Sudarwanto, T. (2019). Development of Vlog Learning Media (Video Tutorial) on Student Materials. Tax at SMK PGRI 1 Jombang. International Journal of Educational Research Review, 435-438. https://doi.org/10.24331/ijere.573945.

Hilmy, M., \& Niam, K. (2020). Winning the Battle of Authorities: The Muslim Disputes Over the Covid-19 Pandemic Plague in Contemporary Indonesia. QIJIS (Qudus International Journal of Islamic Studies), 8(2), 293. https://doi.org/10.21043/qijis.v8i2.7670.

Istuningsih, W., Baedhowi, B., \& Bayu Sangka, K. (2018). The Effectiveness of Scientific Approach Using E-Module Based on Learning Cycle 7E to Improve Students' Learning Outcome. International Journal of Educational Research Review, 3(3), 75-85. https://doi.org/10.24331/ijere.449313.

Kafah, A. K. N., Nulhakim, L., \& Pamungkas, A. S. (2020). Development of video learning media based on powtoon application on the concept of the properties of light for elementary school students. Gravity: Jurnal Ilmiah Penelitian dan Pembelajaran Fisika, 6(1), 34-40. https://doi.org/10.30870/gravity.v6i1.6825.

Kim, D. (2020). The correlation analysis between Korean middle school students' emotional level and friendship in science learning. Jurnal Pendidikan IPA Indonesia, 9(1), 22-31. https://doi.org/10.15294/jpii.v9i1.22744.

Maryani, I., \& Sumiar, Z. (2018). Developing science monopoly on the force learning material for elementary school students. Jurnal Prima Edukasia, 6(1), 11-20. https://doi.org/10.21831/jpe.v6i1.16084.

Megawanti, P., Megawati, E., \& Nurkhafifah, S. (2020). Persepsi Peserta Didik terhadap PJJ pada Masa Pandemi COVID-19. Jurnal Ilmiah Pendidikan, 7(2), 75-82.

Novita, L., Sukmanasa, E., \& Pratama, M. Y. (2019). Penggunaan Media Pembelajaran Video terhadap Hasil Belajar Siswa SD. Indonesian Journal of Primary Education Penggunaan, 3(2), 64-72. http://ejournal.upi.edu/index.php/IJPE/index.

Pamungkas, D. A., Prima, F., \& Arisyanto, P. (2020). Sumber Belajar Dan Media Pembelajaran Dalam Pelaksanaan Kurikulum 2013 Di SDN 1 Pidodowetan. Jurnal Sinektik, 3(2), 164-170. https://doi.org/http://dx.doi.org/10.33061/js.v3i2.3773.

Panjaitan, N. Q., Yetti, E., \& Nurani, Y. (2020). Pengaruh Media Pembelajaran Digital Animasi dan Kepercayaan Diri terhadap Hasil Belajar Pendidikan Agama Islam Anak. Jurnal Obsesi : Jurnal Pendidikan Anak Usia Dini, 4(2), 588. https://doi.org/10.31004/obsesi.v4i2.404.

Pawicara, R., \& Conilie, M. (2020). Analisis Pembelajaran Daring Terhadap Kejenuhan Belajar Mahasiswa Tadris Biologi Iain Jember di Tengah Pandemi Covid-19. ALVEOLI: Jurnal Pendidikan Biologi, 1(1), 29-38. https://doi.org/https://doi.org/10.35719/alveoli.v1i1.7.

Pham, V. H., Cichy, I., Wawrzyniak, S., \& Rokita, A. (2020). "BRAINballs" educational balls - An innovative teaching method in education "Children learn while playing." VNU Journal of Science: Education Research, 36(4), 68-74. https: //doi.org/10.25073/2588-1159/vnuer.4443.

Purwanto, Y., \& Rizki, S. (2015). Pengembangan Bahan Ajar Berbasis Kontekstual Pada Materi Himpunan Berbantu Video Pembelajaran. AKSIOMA Journal of Mathematics Education, 4(1), 67-77. https://doi.org/10.24127/ajpm.v4i1.95.

Purwatiningsih, S. D., \& Soelistyowati, D. (2021). Pembelajaran Online sebagai Solusi Belajar di Masa Pandemi COVID-19. Warta Ikatan Sarjana Komunikasi Indonesia, 4(01), 51-59. https://doi.org/https://doi.org/10.25008/wartaiski.v4i1.110.

Rahmawati, F., Fatimah, V., Buraidah, N. L., El Wa'fa, A. R., Faizah, S. N., \& Mukaromah, A. (2021). Efektivitas Video Belajar Dalam Pembelajaran Daring Matematika Materi Transformasi Pada Siswa Smp. Jurnal THEOREMS (The Original Research of Mathematics), 5(2), 202. https://doi.org/10.31949/th.v5i2.2668.

Sakiah, N. A., \& Effendi, K. N. S. (2021). Analisis Kebutuhan Multimedia Interaktif Berbasis PowerPoint Materi Aljabar Pada Pembelajaran Matematika SMP. JP3M (Jurnal Penelitian Pendidikan dan Pengajaran Matematika), 7(1), 39-48. https://doi.org/10.37058/jp3m.v7i1.2623.

Saputri, D. Y., Rukayah, \& Indriayu, M. (2018). Need Assessment of Interactive Multimedia Based on Game in Elementary School: A Challenge into Learning in 21st Century. International Journal of Educational Research Review, 3(3), 1-8. https://doi.org/10.24331/ijere.411329.

Sari, N. A., Akbar, S., \& Yuniastuti. (2018). Penerapan Pembelajaran Tematik Terpadu di Sekolah Dasar. Jurnal Pendidikan: Teori, Penelitian, dan Pengembangan, 3(12), 1572-1582. https://doi.org/http://dx.doi.org/10.17977/jptpp.v3i12.11796.

Suhendro, E. (2020). Strategi Pembelajaran Pendidikan Anak Usia Dini di Masa Pandemi Covid-19. Golden Age: Jurnal Ilmiah Tumbuh Kembang Anak Usia Dini, 5(3), 133-140. https://doi.org/10.14421/jga.2020.5305. 
Sukmanasa, E., Windiyani, T., \& Novita, L. (2017). Pengembangan Media Pembelajaran Komik Digital Pada Mata Pelajaran Ilmu Pengetahuan Sosial Bagi Siswa Kelas V Sekolah Dasar Di Kota Bogor. Jurnal Pendidikan Sekolah Dasar, 3(2), 171. https://doi.org/10.30870/jpsd.v3i2.2138.

Suratun, Irwandani, \& Latifah, S. (2018). Video Pembelajaran Berbasis Problem Solving Terintegrasi Chanel Youtube: Pengembangan pada Materi Cahaya Kelas VIII SMP. Indonesian Journal of Science and Mathematics Education, 1(3), 271-282. https://doi.org/10.24042/ijsme.v1i3.3602.

Susanti, S. (2020). Praktik Pembelajaran Sejarah Pada Masa Pembelajaran Jarak Jauh (PJJ). HISTORIS : Jurnal Kajian, Penelitian \& Pengembangan Pendidikan Sejarah, 5(2), 102-106. https://doi.org/https://doi.org/10.31764/historis.v5i2.2992.

Syah, A., \& Tasrif, E. (2021). Sistem Pembelajaran Berbasis Teknologi Informasi Dan Komunikasi "Studi Kasus MAS TI Canduang dengan Menggunakan Media Pembelajaran Google Classroom." JAVIT : Jurnal Vokasi Informatika, 1(1), 10-15. https://doi.org/10.24036/javit.v1i1.12.

Tafonao, T. (2018). Peranan Media Pembelajaran Dalam Meningkatkan Minat Belajar Mahasiswa. Jurnal Komunikasi Pendidikan, 2(2), 103. https://doi.org/10.32585/jkp.v2i2.113.

Tegeh, I. M., \& Kirana, I. M. (2010). Metode Penelitian Pengembangan Pendidikan. Universitas Pendidikan Ganesha.

Udjaja, Y., Guizot, V. S., \& Chandra, N. (2018). Gamification for Elementary Mathematics Learning in Indonesia. International Journal of Electrical and Computer Engineering (IJECE), 8(5), 3860. https://doi.org/10.11591/ijece.v8i5.pp3860-3865.

Warju, Ariyanto, S. R., Soeryanto, Hidayatullah, R. S., \& Nurtanto, M. (2020). Practical Learning Innovation: Real Condition Video-Based Direct Instruction Model in Vocational Education. Journal of Educational Science and Technology (EST), 6(1), 79. https://doi.org/10.26858/est.v6i1.12665.

Widodo, W., Sudibyo, E., Suryanti, Sari, D. A. P., Inzanah, \& Setiawan, B. (2020). The effectiveness of gadget-based interactive multimedia in improving generation z's scientific literacy. Jurnal Pendidikan IPA Indonesia, 9(2), 248-256. https://doi.org/10.15294/jpii.v9i2.23208.

Wulandari, R. E., Aksioma, D. F., \& Haryono, H. (2019). Analisis Reliabilitas dan Availabilitas pada Mesin Produksi Lampu Pijar Sistem Seri Menggunakan Pendekatan Analisis Markov di PT. Sinar Angkasa Rungkut. Jurnal Sains dan Seni ITS, 7(2), 7-12. https://doi.org/10.12962/j23373520.v7i2.33178.

Yuanta, F. (2020). Pengembangan Media Video Pembelajaran Ilmu Pengetahuan Sosial pada Siswa Sekolah Dasar. Trapsila: Jurnal Pendidikan Dasar, 1(02), 91. https://doi.org/10.30742/tpd.v1i02.816.

Yudela, S., Putra, A., \& Laswadi, L. (2020). Pengembangan Media Pembelajaran Matematika Berbasis YouTube Pada Materi Perbandingan Trigonometri. Imajiner: Jurnal Matematika dan Pendidikan Matematika, 2(6), 526-539. https://doi.org/10.26877/imajiner.v2i6.7089. 